\title{
Acute renal failure with polyarteritis nodosa and multiple myeloma
}

\author{
A.J. Williams, A.C. Newland ${ }^{1}$ and F.P. Marsh \\ The Departments of Nephrology and 'Haematology, The London Hospital, Whitechapel, London, E.1., UK.
}

\begin{abstract}
Summary: A patient who presented with acute renal failure due to renal cortical necrosis is described. Renal biopsy showed cortical infarction and angiography demonstrated aneurysms in the renal, splenic and hepatic circulations. Concurrently he was found to have an IgA kappa paraprotein with bone marrow changes diagnostic of multiple myeloma. He was treated with haemodialysis, immunosuppressive drugs and plasma exchange but died 3 months after presentation.
\end{abstract}

\section{Introduction}

The cause of polyarteritis nodosa is unknown although there is indirect evidence that immune complexes are involved (Ronco et al., 1983). The condition has been described in association with viral infections (Gocke et al., 1970; Trepo et al., 1974; Drueke et al., 1980; Doherty \& Bradfield, 1981) and various lymphoproliferative disorders (Christianson \& Fine, 1967; Gerber et al., 1972; Elkon et al., 1979) but we have found only one report of polyarteritis nodosa complicating multiple myeloma (Hallen, 1966). Here we describe another such case which presented with acute renal failure.

\section{Case report}

A 51 year old man presented with anuria. Three years previously his renal function was normal when starting anti-hypertensive treatment with methyldopa. He was otherwise well until 4 days before admission when he developed colicky abdominal pain, then arthralgia involving hands, wrists, elbows and ankles, followed by anuria. On examination he was febrile $\left(37.5^{\circ} \mathrm{C}\right)$ and hypertensive (BP 180/100 $\mathrm{mmHg}$ ). He was tender in the left iliac fossa and had a swollen right hand, tenderness over the dorsum of the left foot and a sterile effusion of the right knee. Investigation showed a normochromic normocytic anaemia $(\mathrm{Hb} 7.5 \mathrm{~g} / \mathrm{dl})$, leucocytosis $\left(13.6 \times 10^{9} / 1\right.$; neutrophils $70 \%$, eosinophils $11 \%)$ reduced platelets $\left(125 \times 10^{9} / 1\right)$ and a raised ESR $(119 \mathrm{~mm} / \mathrm{h})$. A clotting screen was normal.

Correspondence: A.J. Williams, M.D., M.R.C.P. The Renal Unit, Morriston Hospital, Swansea, West Glamorgan Accepted: 19 July 1984
Plasma urea was $41.4 \mathrm{mmol} / \mathrm{l}$, creatinine $1208 \mu \mathrm{mol} / \mathrm{l}$, calcium $2.12 \mathrm{mmol} / 1$, alkaline phosphatase $128 \mathrm{IU} / 1$ (normal 30-85 IU/1), urate $726 \mathrm{mmol} / 1$, aspartate transaminase $128 \mathrm{U} / 1$ (normal 15-40 U/1), albumin $28 \mathrm{~g} / \mathrm{l}$ and globulin $37 \mathrm{~g} / \mathrm{l}$. Autoantibody screening was negative, as were tests for hepatitis B surface antigen and cytomegalovirus antibody. Serum complement $\left(\mathrm{C}_{3}, \mathrm{C}_{4}, \mathrm{CH}_{50}\right)$ levels were normal. Immune complex assay using polyethylene glycol precipitation was positive although $\mathrm{C}_{1 \mathrm{a}}$ binding was normal. Cryoglobulins were not detected but a serum immunoglobulin assay showed elevated IgA $(945 \mathrm{mg} / \mathrm{dl}$; normal range $80-274)$ but low IgG $(496 \mathrm{mg} / \mathrm{dl}$; normal range 486-1653) and IgM $(57 \mathrm{mg} / \mathrm{dl}$; normal range 51-183). Immunoelectrophoresis confirmed an IgA kappa paraprotein. Bone marrow aspiration supported the diagnosis of myeloma, with plasma cells - many of bizarre morphology - accounting for more than $16 \%$ of the nucleated cells present.

Chest and skull X-rays and renal ultrasonography were normal. A ${ }^{99} \mathrm{Tc}^{\mathrm{m}}$-DTPA scan showed poor perfusion of both kidneys. Renal and coeliac axis angiography showed changes consistent with renal cortical necrosis (Figure 1) and aneurysms in the renal, splenic and hepatic circulation (Figure 2). Renal biopsy showed cortical necrosis. Some tubules contained red cell casts and many arterioles showed fibroelastic intimal proliferation. Those glomeruli which were not necrosed showed partial collapse and some proliferative changes. Immunofluorescence microscopy was negative.

The patient was dialysed and treated for polyarteritis with antihypertensive drugs, prednisolone, azathioprine, dipyridamole and anticoagulants. Ten plasma exchanges, each of 41 , were carried out over $30 \mathrm{~d}$ in an attempt to reduce his circulating immune 

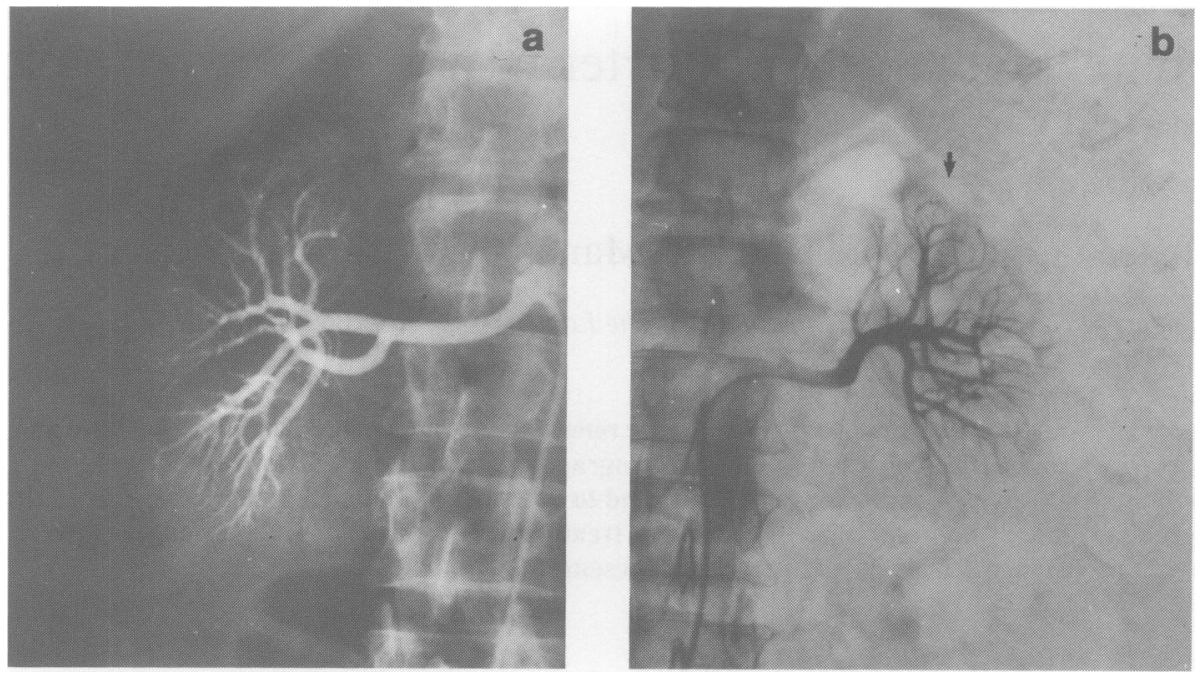

Figure 1 Bilateral renal arteriograms showing microaneurysms and evidence of renal cortical ischaemia. Aneurysms are clearly seen in Figure 1a. In Figure $1 \mathrm{~b}$ a zone of tissue without perfusion can be seen between a capsular vessel (arrowed) and the perfused inner cortex.

complexes. Following diagnosis of multiple myeloma, cyclophosphamide was substituted for azathioprine. He remained anuric and developed severe sepsis, because of which cytotoxic therapy was suspended after 6 weeks. Perforation of the sigmoid colon was

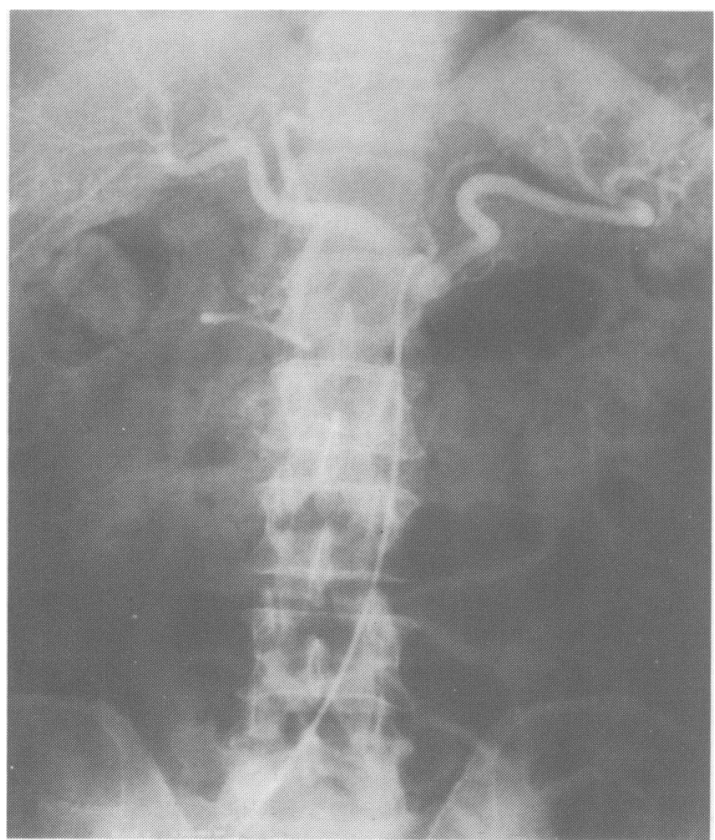

Figure 2 Hepatic and splenic arteriograms showing aneurysms in both organs. complicated by septicaemia and bone marrow depression. He died 3 months after presentation.

\section{Discussion}

Two types of renal lesion are found in polyarteritis. The 'microscopic' variety is characterized by a proliferative, sometimes crescentic glomerulonephritis. In the 'macroscopic' form, medium sized $\stackrel{\odot}{\perp}$ arteries including renal arcuate and interlobar vessels $\overrightarrow{\vec{P}}$ are involved, with disruption of the elastic lamina, $\frac{0}{3}$ fibrinoid necrosis, thrombosis and aneurysm formation. Renal infarction with cortical necrosis, as in our patient, may follow (Ladefoged et al., 1969).

Several of the glomeruli showed proliferative chan- 3 . ges probably due to ischaemia. Alternatively, these may have represented a glomerulonephritis complicat- $\frac{3}{6}$. ing polyarteritis or myeloma, although this is less 0 likely. Such lesions in myeloma are rare, and have been $₹$ thought to be due to the physico-chemical properties 을 of the light chains (Beaufils \& Morel-Maroger, 1978). A nodular glomerulopathy with thickening of glomerular and tubular basement membranes and $N$ mesangial deposits of kappa light chains has been described (Randall et al., 1976; Seymour et al., 1980; N Gallo et al., 1980; Knobler et al., 1983). Sometimes $\mathcal{W}^{2}$ more severe mesangial (Avashti et al., 1977) or intraand extra-capillary cell proliferation with crescento

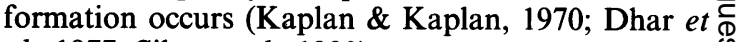
al., 1977; Silva et al., 1980).

The myeloma may have been associated with 0 polyarteritis by chance, but seems more likely to have 
been related aetiologically to it. Polyarteritis has been linked with cryoglobulinaemia, benign IgG paraproteinaemia (Hrncir et al., 1974) and various other lymphoproliferative disorders, in particular hairy cell leukaemia, in which the abnormal cells are capable of immunoglobulin synthesis (Elkon et al., 1979). Such associations could be due to a direct effect of abnormal immunoglobulins, with or without immune complex formation, or to diminished reticuloendothelial clearance of immune complexes which would otherwise not provoke vascular damage (Haakenstad \& Mannik, 1974; Beaufils \& Morel-Maroger, 1978). Evidence for such pathogenic involvement of immune complexes comes from the finding of hypocomplementaemia, cryoglobulinaemia and $\mathrm{C}_{3}$ de-

\section{References}

AVASHTI, P.S., ERICKSON, D.G., WILLIAMS, R.C. \& TUNG, K.S.K. (1977). Benign monoclonal gammaglobulinaemia and glomerulonephritis. American Journal of Medicine, 62, 324.

BEAUFILS, M. \& MOREL-MAROGER, L. (1978). Pathogenesis of renal disease in monoclonal gammopathies: current concepts. Nephron, 20, 125.

CHRISTIANSON, H.B. \& FINE, R.M. (1967). Vasculitis with or without panniculitis in leukaemia, lymphoma and multiple myeloma. Southern Medical Journal, 60, 567.

DHAR, S.K., SMITH, E.C. \& FRESCO, R. (1977). Proliferative glomerulonephritis in monoclonal gammopathy. Nephron, 19, 288.

DOHERTY, M. \& BRADFIELD, J.W. (1981). Polyarteritis nodosa associated with acute cytomegalovirus infection. Annals of Rheumatic Disease, 40, 419.

DRUEKE, T., BARBANEL, C., JUNGERS, P., DIGEOU, M., POISSON, M., BRIVET, F., TRECAN, G., FELDMANN, G., CROSNIER, J. \& BACH, J.F. (1980). Hepatitis B antigen associated periarteritis nodosa in patients undergoing longterm haemodialysis. American Journal of Medicine, 68, 86.

ELKON, K.B., HUGHES, G.R.V., CATOVSKY, D., CLAUVEL, J.P., DUMONT, J., SELIGMANN, M., TANNENBAUM, H. \& ESDAILE, J. (1979). Hairy cell leukaemia with polyarteritis nodosa. Lancet, ii, 280.

FRANKLIN, E.C. (1980). The role of cryoglobulins and immune complexes in vasculitis. Journal of Allergy and Clinical Immunology, 66, 269.

GALLO, G.R., FEINER, H.D., KATZ, L.A., FELDMANN, G.M., CORREA, E.B., CHUBA, J.V. \& BUXBAUM, J.N. (1980). Nodular glomerulopathy associated with non-amyloidotic kappa light chain deposits and excess immunoglobulin light chain synthesis. American Journal of Pathology, 99, 621.

GERBER, M.A., BRODIN, A., STEINBERG, D., VERNACE, S., YONG, C. \& PARONETTO, F. (1972). Periarteritis nodosa, Australia antigen and lymphatic leukaemia. New England Journal of Medicine, 286, 14. position in the glomeruli, in patients with paraproteinaemias (Kaplan \& Kaplan, 1970). In patients with mixed essential cryoglobulinaemia it is thought that a vasculitis with renal involvement can result from deposition of IgG-IgM complexes in vessel walls (Franklin, 1980; Tarantino et al., 1981).

In our patient, cytotoxic therapy and plasma exchange were used in the hope that they would suppress the malignant clone of plasma cells and remove factors responsible for the vasculitis. They reduced the levels of circulating paraproteins and immune complexes but did not benefit him clinically or cause any improvement in renal function. Throughout his illness there was clinical evidence of active vasculitis.

GOCKE, D.J., HSU, K., MORGAN, C., BORMBARDIERI, S., MOCKSHIN, M. \& CHRISTIAN, C.C. (1970). Association between polyarteritis and Australia antigen. Lancet, ii, 1149.

HAAKENSTAD, A.O. \& MANNIK, M. (1974). Saturation of the reticuloendothelial system with soluble immune complexes. Journal of Immunology, 112, 1939.

HALLEN, J. (1966). Discrete gammaglobulin (M-) components in serum. (Clinical study of 150 subjects without myelomatosis). Acta Medica Scandinavica, 181, (Suppl 464), 1.

HRNCIR, Z., MRACEK, J., NOZICKA, Z., TICHY, M., VANASEK, J. \& VODICKOVA, L. (1974). Facultative IgG paraproteinaemia in polyarteritis nodosa. Sbornik vedeckych praci Lekarske fakulty uk v Hradci Kralove, 17, 247.

KAPLAN, N.G. \& KAPLAN, K.C. (1970). Monoclonal gammopathy, glomerulonephritis and the nephrotic syndrome. Archives of Internal Medicine, 125, 696.

KNOBLER, H., KOPOLOVIC, J., KLEINMAN, Y., RUBINGER, D., SILVER, J., FRIEDLAENDER, M.M. \& POPOVTZER, M.M. (1983). Multiple myeloma presenting as dense deposit disease. Light chain nephropathy. Nephron, 34, 58.

LADEFOGED, J., NIELSEN, B., RAASCHOU, F. \& SORENSON, A.W.S. (1969). Acute anuria due to polyarteritis nodosa. American Journal of Medicine, 46, 827.

RANDALL, R.E., WILlIAMSON, W.C., MULLINAX, F., TUNG, M.Y. \& STILL, W.J.C. (1976). Manifestations of systemic light chain deposition. American Journal of Medicine, 60, 293.

RONCO, P., VERROUST, P., MIGNON, F., KOURILSKY, O., VANHILLE, P.H., MEYRIER, A., MERY, Ph. \& MORELMAROGER, L. (1983). Immunopathological studies of polyarteritis nodosa and Wegener's granulomatosis: a report of 43 patients with 51 renal biopsies. Quarterly Journal of Medicine, 206, 212.

SEYMOUR, A.E., THOMPSON, A.J., SMITH, P.S., WOODROFFE, A.J. \& CLARKSON, A.R. (1980). Kappa light chain glomerulosclerosis in multiple myeloma. American Journal of Pathology, 101, 557. 
SILVA, F.G., MEYRIER, A., MOREL-MAROGER, L. \& PIRANI, C.L. (1980). Proliferative glomerulonephropathy in multiple myeloma. Journal of Pathology, 130, 229.

TARANTINO, A., DE VECCHI, A., MONTAGNINO, G., IMBASCIATI, F., MIHATSCH, M.J., ZOLLINGER, H.U., BARBIANO DI BELGIOJARO, G., BUSNACH, G. \& PONTICELLI, C. (1981). Renal disease in essential mixed cryoglobulinaemia. Longterm follow-up of 44 patients. Quarterly Journal of Medicine, 50, 1.

TREPO, C.G., ZUCKERMAN, A.J., BIRD, R.C. \& PRINCE, A.M. (1974). The role of circulating hepatitis $B$ antigen $-\mathbb{Q}$ antibody immune complexes in the pathogenesis of vas- $c$ cular and hepatic manifestations in polyarteritis nodosa. Journal of Clinical Pathology, 27, 863. 